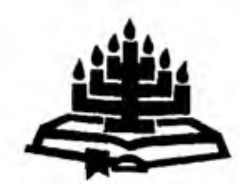

\title{
De liefde van Christus dringt ons - missionaire ecclesiologie bij Dietrich Bonhoeffer'
}

\author{
J.W. Maris \\ Departement Dogmatische Vakken \\ Theologische Universiteit \\ APELDOORN \\ Nederland \\ E-pos: theol.tua@wxs.n!
}

\section{Abstract \\ The love of Christ compels us - Dietrich Bonhoeffer's missionary ecclesiology}

This article focuses on Bonhoeffer's thoughts on the missionary presence of the church in the world. In the discussion two books by Bonhoeffer are mainly referred to: his Nachfolge (1937) and his Ethik (1943). Although features in his theological thinking remind us of a universalism like that of Karl Barth, the biblical content of his writings is of such quality that we are compelled to take him very seriously.

It is not only when Bonhoeffer writes on the way in which Jesus Christ exists in the church that an impact on a Reformed Bible-believing theologian is activated, but his convictions about the reality of the existence of the church in the world also remain worthy of consideration. Great harmony exists in the way in which Bonhoeffer outlines the calling to be a witness to the world and the way in which he deals with the participation of

I Voor een artikel waarmee prof. Koos van Rooy wordt geierd, ligt het voor de hand te denken aan een onderwerp op het grensgebied tussen kerk en zending.

In de ontmoeting tussen de Christelijke Gereformeerde Kerken in Nederland en die Gereformeerde Kerke van Suid-Afrika heeft de zending door de jaren heen een grote rol gespeeld Juist daarin heeft Koos van Rooy, als zendeling door de kerk in Nederland geroepen naar Venda, een belangrijke functie vervuld Daarin hebben we hem leren kennen als zendeling tussen het volk, en zo als missioloog. De noodzaak dat de kerk haar gerichtheid op de zending niet als een eventuele mogelijkheid zou beschouwen, maar als even noodzakelijk als een kerkorde of een kerkgebouw of een ouderling, heeft in zijn persoonlijke houdmg gestalte gekregen. 
Christians in the world. Bonhoeffer, however, does not ignore the tension between church and world, and between belief and unbelief.

Perhaps the most prominent feature of his theology deserving our attention is his plea for the unity of a Christian life style in this world-a world that does not belong to us but to God.

\section{Een uitdaging voor gereformeerden}

Men kan zeggen dat de belangstelling voor de zending als wezenlijk aspect van het bestaan van de kerk is toegenomen. Het is immers niet altijd als vanzelfsprekend gezien, dat de bezinning op de zending deel uitmaakt van de leer aangaande de kerk. In de dogmatiek van $\mathrm{H}$. Bavinck wordt slechts zeer terloops over de zending gesproken (Bavinck, 1976:135). Hetzelfde geldt van de recente dogmatiek van Van Genderen en Velema (1992:628 e.v.). In de dogmatische studièn van G.C. Berkouwer over de kerk heeft de zending wel een plaats - in het allerlaatste hoofdstuk. Hij gaat vooral in op de discussie over de vraag of de kerk slechts present moet zijn in de wereld of daarin ook geroepen is tot getuigen (Berkouwer, 1972:226-262). Duidelijk positief spreekt de Afrikaanse dogmatiek van J.A. Heyns, bij wie men de zin kan lezen "Die kerk van Christus is na sy diepste wese sendingkerk" (Heyns, 1978:373).

In het algemeen zijn gereformeerden zeker niet meegegaan met de gedachte van een theoloog als J.C. Hoekendijk voor wie de kerk slechts een functie was van het apostolaat. Dat de kerk ook een eigen reden van bestaan heeft als lichaam van Christus wordt door hem vergeten. Alleen de functie van de kerk, het er-zijn voor de wereld, is nog van belang (Hoekendijk, 1964:51, 56 e.v.). Ook andere voorstellingen die vooral in de jaren zestig van de $20 \mathrm{e}$ eeuw modieus waren, hebben in de gereformeerde theologie weinig gehoor gevonden, al heeft de golfslag van de discussie hen wel geraakt. Te denken is dan vooral aan de wijze waarop in die jaren de God-is-dood-theologie werd ontwikkeld. In het spoor van voorgangers als Rudolf Bultmann, Paul Tillich en anderen hebben diverse theologen geprobeerd de kennis van God en zijn openbaring om te duiden tot iets dat in metaforen een soort dieptedimensie van het menselijk bestaan en de samenleving weergeeft.

Als een steen in een vijuer heeft in die jaren het werk van de anglicaanse bisschop John A.T. Robinson, Honest to God (1963), discussie opgeroepen. De transcendentie van God is bij hem geheel ondergegaan in de verhouding van de mens tot zijn medemens. Zijn boekje baarde vooral veel opzien, omdat hij zich als bisschop zo radicaal vrijzinnig uitte. Dat het de christenheid theologisch iets nieuws bracht, kan niet worden gezegd. Waarom ik hem hier noem is, omdat hij zich voor zijn gedachten, behaive op Bultmann en Tillich, ook beriep op Dietrich Bonhoeffer. Met name diens pleidooi voor een "religieloos christendom" werd door Robinson toegejuicht. Als "verdienste" van Robinson kan worden genoemd, 
dat hij Bonhoeffer zo nadrukkelijk in de belangstelling heeft geplaatst. Verder is ieder het er sindsdien wel over eens, dat zijn weergave van Bonhoeffer oppervlakkig en onjuist was (Runia, z.j.:99).

De naam van Bonhoeffer speelde ook bij de genoemde Hoekendijk al een rol. Na deze aanvankelijke commotie waarin de naam van Bonhoeffer een rol speelde, heeft de bestudering van Bonhoeffer intussen in een veelheid van werken over hem een heel wat genuanceerder beeld opgeroepen. We zullen er dan ook goed aan doen op het punt van de vraag naar de roeping van de kerk in de wereld met zijn werk bezig te zijn. Dat is wat dit artikel beoogt. Het verstaan van Bonhoeffer is er niet mee gediend als dat alleen door de bril van vrijzinnige theologen gebeurt.

Daarmee is nog niet gezegd, dat we hem als kerkvader van een bijbelgetrouwe, aan de belijdenis gebonden kerk kunnen beschouwen, zoals dat door G. Huntemann is bepleit (Huntemann, 1989:258). Er ligt voor ons echter nog altijd een uitdaging in Bonhoeffers werk, die vergeleken kan worden met de betekenis van de ecclesiologische studies van J.E. Lesslie Newbigin, die overigens veel uitdrukkelijker het thema van de zending op de agenda van de kerk heeft geplaatst. $^{2}$

\section{De kerk in het hart van Bonhoeffers theologie}

Reeds in zijn dissertatie, Sanctorum Communio, uit 1930 (Bonhoeffer, 1954), is Bonhoeffer intensief bezig met de leer van de kerk. Het gaat hem om de verbinding tussen de kerk als geloofswerkelijkheid en de kerk als empinisch gegeven. Hij erkent dat naar beide kanten de benadering van de kerk verkeerd kan gaan. Het religieuze misverstand zou er toe kunnen leiden de kerk slechts als eschatologische werkelijkheid te zien; en dan is de reële historische gestalte van de kerk niet meer van belang. Bij het misverstand aan de andere kant, door de kerk als historische, sociologische grootheid te benaderen, worden de menselijke beperkingen te weinig gezien. Dan kan bijv. de historische gestalte van de hiërarchische theocratie van de Roomse kerk verabsoluteerd worden, maar dan wordt de geloofsdimensie van de kerk gemist. Bonhoeffer wil beide vasthouden: de fenomenologische en de theologische betekenis van de kerk, de historische en de eschatologische, de menselijke en de goddelijke (Moltmann \& Weissbach, 1967:25).

Men kan zeggen, dat er later bij Bonhoeffer een ingrijpende oriëntatiewisseling heeft plaatsgevonden - van een gerichtheid op de kerk naar een gerichtheid op de wereld. H. Müller heeft gezegd dat deze wisseling te maken heeft met de

2 Een beknopte orièntatie in het veld van de missionaire ecclesiologie, waarbij met name de onlangs overleden Lesslie Newbigin aandacht krijgt, is te vinden bij Jongeneel (1991:82-85). 
historische tegenstrijdigheden die Bonhoeffer meemaakte (Müller, 1961:9). Inderdaad kon hij aanvankelijk nog tamelijk onbekommerd bezig zijn met de vragen van de kerk. Na de turbulente omslag in de Duitse en Westeuropese samenleving, die hemzelf in de gevangenis deed belanden, heeft Bonhoeffer beseft, dat de veranderingen gevolgen hadden voor de manier waarop theologie bedreven moest worden. In een van zijn brieven uit de gevangenschap, in de bundel Widerstand und Ergebung, in de zomer van 1944 geschreven aan zijn vriend Eberhard Bethge, komt uit hoe naar zijn besef, de nieuwe tijd ook nieuwe vragen aan de kerk stelt. "Hoe kan Christus de Heer ook van religielozen worden? Bestaan er christenen zonder religie?" (Bonhoeffer, 1966:1-33).

De vraag naar Christus is voor Bonhoeffer in wezen een vraag naar de kerk. Voor hem valt, net als voor Karl Barth, alle nadruk op de centrale betekenis van Christus in het midden van de menselijke existentie, en in het midden van de geschiedenis. Reeds in zijn Sanctorum Communio staat de stelling centraal, dat Christus als gemeente existeert (Bonhoeffer, 1954:92). Een verschil met Barth is dat Bonhoeffer veel meer oog heeft voor de werkelijkheid van de geschiedenis. Het diepste probleem van de theologie van Karl Barth is wellicht dat deze uiteindelijk onhistorisch denkt, en dat hij de verbinding tussen de heilsgeschiedenis en de concrete geschiedenis van de wereld als het erop aankomt niet leggen kan. Bij Bonhoeffer blijkt een diepe behoefte te bestaan om de werkelijkheid van Christus ook midden in de situatie van de wereld gestalte te zien krijgen.

De centrale plaats van Christus zal gevolgen moeten hebben midden in de concrete geschiedenis. Dat is de zorg waar Bonhoeffer nog in de gevangenis mee bezig was.

Wat betekent een kerk, een gemeente, een preek, een liturgie, een christelijk leven, in een religieloze wereld? ... Hoe spreken (of misschien kunnen wij daar niet eens meer over 'spreken', zoals tot dusver) wij 'wereldlijk' over 'God', hoe zijn wij ek-klésia, naar-buiten-geroepene, zonder ons als religieus bevoorrechten te beschouwen, maar veel meer als helemaal aan de wereld toebehorende? (Bonhoeffer, 1966:133-134).

In deze omslag in zijn denken, die alles te maken had met zijn zorg voor een van God vervreemde wereld, ligt dus toch een grote mate van continuiteit met de manier waarop hij eerder over de kerk sprak als de gestalte bij uitstek van de tegenwoordigheid van Christus. De nieuwe vraag naar de tegenwoordigheid van Christus in de wereld zoals deze onder het regiem van het nationaal-socialisme geworden is, is dan ook tegelijkertijd een vraag naar de tegenwoordigheid van de kerk in de wereld.

Het volgen van de gedachten van Bonhoeffer zet ook voor ons onze christelijke existentie op scherp. Wanneer hij concreet op de realiteit van de politieke context 
van zijn dagen ingaat, weet hij welke risico's hij neemt. In zijn Widerstand und Ergebung (1966), voornamelijk brieven geschreven in gevangenschap, wordt duidelijk dat zijn denken ook tegen het licht van de laatste ernst van het leven, de dood, kan worden getoetst. En hij weet dat zelf. Keer op keer blijkt voor hem de laatste ernst van het leven niet slechts de dood, maar ook het geloof in Christus te zijn. Ook in die situatie blijft hij bezig met zijn theologie, in terugblikken, in evaluaties, in het als het ware uitkleden tot op het bot van de laatste waarheid. De franje moest er af. Daar vooral ligt naar mijn gedachte de waarheid van zijn pleidooi voor een zogenaamd religieloos christendom. Juist in Duitsland had Bonhoeffer heel wat religieus christendom gezien dat ten diepste een verloochening van Christus inhield. In de kringen van de "deutsche Christen" wist men een uitwendig christelijk bestaan te combineren met een diepgaande solidariteit met Hitlers soort nationalisme. Het antisemitisme, tesamen met de andere vormen van racisme die door Hitler en de zijnen werden gepredikt, kòn echter niet met het geloof in Christus verenigd worden. Daar lag voor Bonhoeffer de diepe ernst van zijn religieloos christendom. Het ging om de herkenbaarheid van Christus tot op de draad van een eerlijk praktisch belijden van de christenen. Op die manier ging het hem om de kerk en haar geloofwaardigheid, en om haar trouw aan het evangelie.

Wanneer de eerder genoemde bisschop Robinson zich in de jaren zestig van de twintigste eeuw dan ook beroept op Bonhoeffer voor een religieloos christendom, bedoelt hij heel iets anders. Hij heeft niet de belijdenis van Christus op het oog, maar een geseculariseerde levenshouding, waarin niet de Christus der Schriften, maar een horizontalistisch en humanistisch maatschappij-ideaal zijn denken bepaalt. Bij Robinson bleef er weinig over van Christus, en even weinig van de kerk.

Bij Bonhoeffer daarentegen ging het wel om het wezenlijke van het belijden van de kerk. Er is geen sprake van dat bij hem een beweging van de kerk af naar de wereld zichtbaar werd. Men kan beter zeggen dat Bonhoeffer steeds meer bezig geweest is met de beweging die juist de kerk moet maken naar de wereld toe. Dat is iets heel anders! Bonhoeffer was zich ervan bewust met hoe grote moeiten het maken van deze beweging - men kan ook zeggen: het volgen van deze roeping gepaard ging. Zijn levensgeschiedenis is het bewijs van de waarachtigheid van zijn theologisch werk. Niet bij veel theologen is dat op zo'n radicale manier het geval geweest.

Om iets van Bonhoeffers gedachten weer te geven concentrerem we ons voomamelijk op twee van zijn boeken: Nachfolge uit 1937 en de eerst na zijn dood als zijn Ethik gepubliceerde en gerubriceerde manuscripten die zijn geschreven tussen 1940 en 1943. In de laatste uitgave van dit werk, in de mooie nieuwe editie van zijn geschriften, de Dietrich Bonhoeffer Werke, is dit werk voor het eerst verschenen in de gereconstrueerde volgorde waarin deze 
manuscripten geschreven zijn. Tijdens het werk aan de Ethik werd Dietrich Bonhoeffer op 5 april 1943 gearresteerd, om twee jaar later, op 9 april 1945 te worden opgehangen.

In beide werken, Nachfolge en Ethik, is hij nog steeds intens bezig met de vraag naar de betekenis en de roeping van de kerk.

\section{Navolging}

\subsection{Geen goedkope genade}

Men kan het prachtige boek over de navolging van Christus beschouwen als een monument opgericht voor de kracht van het Woord van God. Bonhoeffer kwam niet uit een traditie waarin de Schriften als het Woord van God hoog in ere waren. Zijn afkomst was vrijzinnig. Maar wie met name in dit boek leest hoe hij gegrepen is door het Woord van God Zelf, moet daar diep van onder de indruk raken.

Dat wordt duidelijk in de wijze waarop hij over de goedkope genade spreekt. Het fundament van de kerk is gelegen in de dure genade, die van het kruis van Golgotha. Toen echter het christendom zich uitbreidde en de kerk verwereldlijkte ging de kennis van de dure genade langzamerhand verloren. De wereld werd gechristianiseerd, de genade werd daarmee gemeengoed, en dus tot een goedkoop artikel gemaakt. In de kerk van de middeleeuwen was aanvankelijk alleen in het monnikenleven nog een protest tegen de verwereldlijking van het christendom te vinden (Bonhoeffer, 1994:32-33).

Indringend beschrijft hij hoe in de geschiedenis het christendom tot wereld geworden is, en hoe de christenen door de "billige Gnade" de navolging van Christus zijn kwijtgeraakt, ervan werden beroofd (Bonhoeffer, 1994:37; cf. Kamphuis, 1997:129-131).

Men kan zeggen dat in deze tekening haarscherp de waarheid van de antithese tussen het rijk van God en het rijk van de duistemis wordt geschetst. Wij zijn er misschien wat minder aan gewend die antithese in zo nauwe verbinding met het probleem van de christelijke samenleving te zien. Hoe zal er echter voor de volgelingen van Jezus nog van de navolging van Hem sprake zijn, wanneer de hele samenleving een christelijk stempel heeft ontvangen, en het christendom tot een vanzelfsprekende cultuur geworden is? Wanneer de kerk tot een even vanzelfsprekend element binnen die samenleving geworden is, wat is er dan nog van het wezenlijke van de kerk over? Ook in dit boek komt Bonhoeffer regelmatig terug op de gedachte dat de kerk de tegenwoordige Christus zelf is. Sinds Pinksteren leeft Christus op aarde in de gestalte van zijn lichaam, de gemeente. Zo is de kerk de nieuwe mens, naar God geschapen in gerechtigheid, 
heiligheid en waarheid (Ef. 2:15; 4:24). Dikwijls stelt hij Christus met de kerk gelijk (Bonhoeffer, 1994:232-233). Dat roept dan ook om een herkenbare aanwezigheid van de kerk in de wereld, niet als een exponent van welke samenlevingsvorm dan ook, maar als een exponent van Christus! (cf. Kamphuis, 1997: 132 e.v.)

Naar aanleiding van Matteüs 5:13 e.v. "Gij zijt het licht der wereld" en: "gij zijt het zout der aarde" spreekt Bonhoeffer over het oordeel dat de gemeente van Christus' discipelen bedreigt. De aarde moet immers door de gemeente behouden worden; wanneer dan de gemeente ophoudt te zijn wat zij is, is zij reddeloos verloren (Bonhoeffer, 1994:112).

In de samenleving van Europa en van Afrika, aangevreten als deze thans worden door de geseculariseerdheid van het postmoderne denken, heeft de kerk er baat bij zich door deze gedachten van Bonhoeffer wakker te laten schudden. Een vanzelfsprekende christelijke samenleving is ons in Europa al wat langer ontglipt. In Zuid-Afrika hebben de ontwikkelingen van de laatste jaren ervoor gezorgd dat de kerk evenzeer geen zekerheid meer van de landscultuur te wachten heeft. Beter dan te klagen over wat ons ontvallen is, is stellig de roepstem van Christus te horen om in elk geval weer kerk te zijn naar de maatstaf van Christus. Dat is: naar de maatstaf van het dure evangelie, en niet van een goedkope, in de structuur van menselijke wetten gelegen christelijkheid. Hoe gemakkelijk heeft dat zout zijn smaak verloren zonder dat we het bemerkt hebben! En hoe ernstig is dat!

John de Gruchy heeft terecht gezegd, dat theologie bedrijven in dialoog met Bonhoeffer, en dus verstaan waar het in die theologie ten diepste om gaat, toewijding vereist aan de geknuisigde Here in het midden van de wereld (De Gruchy, 1984:43). Waar in zijn benadering evenwel het zwaartepunt ligt op de bevrijding van bevoorrechte burgers uit de verslaving aan hun voorrechten, en op de legitimiteit van burgerlijk verzet, zal het waardevol zijn juist Bonhoeffers concentratie op de navolging van Christus zelf in haar bevrijdende kracht ter harte te nemen. Daarbij is de noodzaak van een persoonlijke verhouding met Christus geen ogenblik uit het oog te verliezen. Zó zal daar ook voor de verhoudingen in de samenleving heil uit voortvloeien.

\subsection{Christocentrisch zlen naar de naaste}

Intens heeft Bonhoeffer, luisterend naar de Bergrede, gevraagd naar de wijze waarop de naaste voor een christen in beeld is. Opmerkelijk is het hoe nadrukkelijk hij daarbij het woord discipel gebruikt. Wat een mens werkelijk moet leren in de navolging van Christus is Zijn discipel te zijn. Veel uitspraken van Bonhoeffer krijgen zo een grote intensiteit, die zijn kracht tot op de dag van vandaag behouden heeft. Hij zegt: tussen de discipel en de ander staat niet een maatstaf van het rechtvaardige leven, maar alleen Jezus Christus zelf. De discipel 
ziet de naaste steeds alleen maar als iemand tot wie Christus komt! (Bonhoeffer, 1994:177). Dat is christocentrische theologie in hoge concentratie.

Men kan de vraag stellen of bij Bonhoeffer hier niet een denkwijze over de wereld meespeelt die verwant is aan Karl Barth. Dat is inderdaad het geval. Hij spreekt over de liefde van Christus die de ander ziet onder het kruis, en die daarom in waarheid ziende is (Bonhoeffer, 1994:179). Bonhoeffer is ervan overtuigd, dat de wereld, of ze het weet of niet, al in betrekking tot Christus staat. Het verschil tussen de kerk en de wereld bestaat daarin, dat de kerk de werkelijkheid van het door God aangenomen zijn, die voor de hele wereld geldt, gelovig voor zich laat gelden, en juist daarin als voor de hele wereld geldend betuigt (Bonhoeffer, 1992:54). Wellicht is dat de reden waarom hij vooral over de liefde van Christus spreekt die naar de wereld uitgaat. Niet altijd wanneer dat ook verwacht zou kunnen worden, spreekt hij van de roeping tot getuigen in de wereld, en van de noodzaak dat een beslissing genomen zal worden in relatie tot het evangehe. De beslissing voor de wereld is immers al gevallen in Christus. Toch zijn rechtzinnige gereformeerden die hier vragen bij stellen dan nog niet van hem af. Ook voor hen betekent de radicale wijze waarop hij spreekt over een discipel die in een totaal christelijk bestaan gedrongen wordt door de liefde van Christus, een dringend appel.

In deze en dergelijke passages is duidelijk, dat er een innerlijke samenhang is tussen de noodzakelijke persoonlijke heiliging, waar juist in Nachfolge zoveel over wordt gezegd, en het bestaan van de kerk. Dat heeft alles te maken met het feit, dat de kerk lichaam van Christus is. In de kerk, in de in Woord en sacrament vergaderde gemeente, leeft de verkondiging van Christus. Juist omdat in de kerk de levensgemeenschap met Christus is, breekt zij in de wereld in en ontrukt zij aan de wereld haar kinderen. Zo blijkt de kracht van de in de kerk levende Here (Bonhoeffer, 1994:245, 249).

Het is de centrale plaats van Christus die op deze manier de gemeente haar plaats in de wereld wijst. Zending is niet maar een roeping die de kerk eventueel tot de hare kan maken. Zending is onlosmakelijk verbonden met wat de gemeente van Christus is. De steeds terugkerende gedachte dat Christus zichtbaar wordt in de kerk, is geen pro memorie-post. Er kan niet stilzwijgend van worden uitgegaan! Het is een boodschap die de kerk zwaar maakt van de liefde van Christus. Zo kan toch alleen worden verstaan, dat gezegd wordt: "Im Leibe Christi sind wir "wie Christus' geworden" (Bonhoeffer, 1994:303). In de kerk zal de werkelijkheid van de gemeenschap met Christus aan de orde moeten worden gesteld, in het Woord en in het geloof. Het is een zeer indringend vermaan aan de gemeente. De kerk zal zich krachtig moeten inprenten dat zij geen doel in zichzelf is. Dikwijls is de vermaning bij Bonhoeffer terug te vinden dat de kerk en het christelijke leven geen Selbstzweck is. De gemeenschap der heiligen zal door de liefde van Christus die daarin zichtbaar wordt, een boodschap aan de wereld hebben! Wie tot het 
lichaam van Christus behoort, die is uit de wereld verlost en daaruit geroepen, en die moet voor de wereld zichtbaar worden door de nieuwe gemeenschap "des brüderlichen Lebens" (Bonhoeffer, 1994:252).

De innerlijke samenhang tussen Christus en de kerk, en de roeping van de kerk in de wereld, blijkt op deze wijze alles te maken te hebben met de concrete heiliging van de christenen.

\subsection{Heiliging: de zichtbaarheid van de gemeente}

De roeping tot heiliging is voor Bonhoeffer geen individuele zaak. Enerzijds legt hij het verband met de verzegeling door de Heilige Geest, die een zaak van de gemeente is: de gemeente wordt door de inwoning van de Heilige Geest verzegeld tegenover de wereld (Bonhoeffer, 1994:277). Anderzijds legt hij een sterk verband tussen de heiliging en de zichtbaarheid van de gemeente. In de kracht van het zegel van de Geest moet de gemeente Gods aanspraak op de hele wereld laten gelden. Het nieuwe leven van een christen is geen doel in zichzelf het staat in dienst van de boodschap, "dat de aarde en al wat daarin is des Heren is". Zonder de kerk kan deze claim van God op de wereld geen gestalte krijgen in het leven van een individueel christen. Zelfs kan Bonhoeffer zeggen, dat heiliging buiten de zichtbare gemeente Selbtsheiligsprechung is (Bonhoeffer, 1994:278).

Met andere woorden: er is geen persoonlijke heiliging zonder een intense verbinding met de gemeente; en er is geen gemeente zonder een intens besef van de aanspraak van God in Christus op de wereld.

Deze dubbele beweging is maar niet een uiting van een christelijk besef dat de dingen zo zijn - deze beweging is de beweging van de Heilige Geest.

Uitdrukkelijk is ook de kerkelijke tucht in samenhang met dit doel van de heiliging te zien. Het gaat om de heilige gemeente, die als afgescheiden van de wereld aan het licht moet treden. Een gemeente die niet de afzondering van de wereld kent, waarachtig levend onder Gods vergevende barmhartigheid, kan immers haar roeping om licht der wereld te zijn, niet vervullen. De kerkelijke tucht staat op deze wijze in dienst van de dure genade van God. De vermaning en de biecht, die moet leiden tot vergeving, doortrekt zo het hele leven van de gemeente (Bonhoeffer, 1994:286 e.v.).

Meer dan dikwijls bij gereformeerden het geval is, is hier de heiliging gericht op het leven van de kerk, en op de roeping van de kerk. Vele bladzijden wijdt Bonhoeffer wel, op een klemmende manier, aan de betekenis die het Woord van God in wet en evangelie ook voor de persoonlijke heiliging heeft, maar indringend komt daarbij de roeping op ieder af om zich verantwoordelijk te weten voor de kerk, en komt de roeping op de kerk af om zich verantwoordelijk te weten voor de wereld. 
Het ter harte nemen van dit krachtige beroep op ons hart heeft betekenis voor de christenen - juist in een maatschappij die tegen het einde van het millennium in alle opzichten een vrijblijvende samenleving aan het worden is.

God geve ons dat de kracht van het evangelie, die niet afhankelijk is van de beweging van de cultuur in een bepaalde periode, ons van deze verantwoordelijkheid diep doordringt.

\subsection{Zending: Gods eigen werk}

Wat gaande is in de wereld tussen het rijk van God en het rijk van de duistemis is geen zaak van mensen. De scheiding en het gericht wordt niet door de gemeente voltrokken. Het is Gods eigen zaak. In de roeping door Zijn Woord moet er een scheiding zichtbaar worden tussen geloof en ongeloof (Bonhoeffer, 1994:184). Zo moet de gemeente rekening houden met de werkelijkheid van valse profeten in haar eigen midden. De duivel drijft ze de kerk binnen. Het is niet onze roeping ze te ontmaskeren voor de tijd daar is. Wel dienen de gelovigen waakzaam te zijn. Uit de vruchten blijkt immers wat de inhoud van iemands leven is. Schijnchristenen kunnen op een ogenblik aan het licht treden als zodanig. Ten laatste zal echter de grote scheiding plaats hebben op de jongste dag; dan is de scheiding, het oordeel, definitief. Duidelijk spreekt Bonhoeffer over de grote ernst van het gericht van God, dat ook een eeuwig oordeel blijkt te zijn (Bonhoeffer, 1994:189, 203, 207-209).

Het is tegen de achtergrond van deze laatste ernst, dat de zending ter sprake komt. De roeping tot zending is geen mensenwerk. Evenmin als het oordeel aan mensen toekomt, evenmin is de opdracht om tot de heidenen te gaan mensenwerk. Naar de heidenen gaan is Gods werk! Christenen kunnen niet zelf hun arbeidsveld kiezen (Bonhoeffer, 1994:198). Als we doordrongen zijn van de liefde van Christus die ons drijft, dan beseffen wij hoe totaal anders dit is dan elke menselijke motivatie. Bedoelt Bonhoeffer daarmee een ultiem subjectivisme aan te wakkeren, een zich aangestoken voelen door de liefde van Christus? Het tegendeel is het geval. Als hij spreekt over de liefde van Christus die ons dringt, maakt hij ogenblikkelijk duidelijk, dat deze liefde zich onderscheidt van de drang en de ijver van ons eigen hart. In welk opzicht? "Daarin dat de liefde van Christus zich aan de opdracht houdt" (Bonhoeffer, 1994:198). Een bijzonder sterke oriëntatie op de Zender klinkt daarin door! Het diepste motief voor de zending ligt niet in onze liefde, maar in de liefde van Christus. Zo klinkt het zendingsbevel van Matteüs 28 pas zuiver door in de kerk. Niet onze liefde, maar die van Christus; niet ons besef geroepen te zijn, maar zijn bevel dat roept. En het is Zijn liefde die Hem doet roepen. Zo worden de apostelen gebonden aan het woord, aan de opdracht. 
Zo heeft ook de kerk van vandaag te leven bij het Woord. Wat een waardevolle ontdekking als dat voor ons geen tegenstelling is met het leven bij de liefde van Christus! Dan heeft de gemeente bijna "automatisch" het zendingsvuur van de ware discipelen van Jezus.

\section{Ethiek en zending}

\subsection{De kerk als gestalte van Christus}

Ook in de Ethik van Bonhoeffer is het een grondgedachte, dat de kerk de gestalte van Christus is. Daarmee is geen statische realiteit bedoeld. Er zit een goddelijke drang achter, een goddelijke "missionaire" drang, zou men kunnen zeggen. Bonhoeffer spreekt van het verlangen van de mensgeworden God om in alle mensen gestalte te krijgen. Dat verlangen is evenwel nog niet vervuld. Hij die de gestalte van de mens heeft aangenomen, kan slechts in een kleine schare gestalte krijgen: dat is zijn kerk (Bonhoeffer, 1992:83). Daarmee is de voorlopigheid van de kerk aangeduid. Met de kerk is nog niet het einddoel van God bereikt. De kerk draagt slechts de gestalte die in waarheid de hele mensheid geldt (Bonhoeffer, 1992:84).

Deze woorden kunnen verstaan worden als een universalistisch credo, gericht op het uiteindelijke behoud van alle mensen. Er zijn inderdaad meer zulke passages bij Bonhoeffer te vinden, vooral wanneer Gods beweging naar de wereld getekend wordt als een die niet slechts in de kerk en in het evangelie te vinden is, maar ook als een rechtstreekse beweging, zodat in de wereld al een openbaring van Gods goedheid aanwezig is (vgl. Ford, 1994:62). De vraag die daarbij past, is of deze tweede beweging de kerk niet van haar roeping zou beroven!

Intussen mag wel worden bedacht dat Bonhoeffer zijn Ethik niet zelf heeft afgemaakt. De voomaamste bedoeling van dit artikel is ook niet om een afgeronde karakteristiek van Bonhoeffers inzichten te geven, maar om enkele gedachten van hem door te geven die voor de kerk van vandaag vruchtbaar zijn. Er zijn immers ondanks de vragen die gesteld kunnen worden zoveel schatten bij hem te vinden, die gegroeid zijn aan een intensief luisteren naar de Schrift.

Wat betreft het universalistisch lijkende spreken van Bonhoeffer is ook een andere mogelijkheid aanwezig, namelijk dat de kerk de gestalte van de waarheid draagt waar het God met zijn schepping uiteindelijk om begonnen is. Wanneer het laatste oordeel is geweest zal God "alles en in allen" zijn (1 Kor. 15:28). Op diverse plaatsen is duidelijk dat Bonhoeffer de realiteit van het oordeel, ook van het eeuwige oordeel, op een schrifturrlijke wijze laat staan.

In het kader van de Ethik moet bovendien bedacht worden, dat Bonhoeffer hier spreekt over de "Ethik als Gestaltung" (Bonhoeffer, 1992:62-90). Het gaat erom, 
dat het leven van de kerk zichtbaar wordt als een gestalte van de uiteindelijke bedoeling die God met de schepping heeft en zal volvoeren. Een sterk eschatologisch bewustzijn doortrekt zijn schrijven. De kerk dient een doel, een toekomst. Van dat besef hebben discipelen van Jezus vervuld te zijn.

Daarin is de kerk in absolute zin onderworpen aan - ja - eigendom van Christus.

\subsection{Kerk en wereld - de roeping}

De kerk moet weten, dat ook de wereld in betrekking staat tot Christus, of ze het weet of niet. Het is een abstractie om over de wereld te spreken zonder Christus. Het verschil tussen kerk en wereld bestaat volgens Bonhoeffer daarin, dat de kerk de werkelijkheid van het door Christus aangenomen zijn, die de hele wereld geldt, gelovig voor zich laat gelden, en juist daarin deze werkelijkheid als voor de hele wereld geldend betuigt (Bonhoeffer, 1992:54). Het is nochtans duidelijk dat deze gedachtegang moeilijk te duiden is zonder aan een universalistische uitkomst van de geschiedenis te denken. Wij zouden het moeilijk op dezelfde manier kunnen zeggen. Dit betekent niet, dat in het denken van Bonhoeffer in dit opzicht geen uitdagingen zitten voor de kerk van vandaag. Wanneer hij immers zegt dat de kerk zich in het christelijk leven moet oefenen onder de vier mandaten van God die voor hem centraal staan (Bonhoeffer, 1992:55) - de arbeid, het huwelijk, de overheid en de kerk - dan zit ook daar een missionair element in dat voor ons nog van grote betekenis is ${ }^{3}$ Het goddelijke van deze mandaten komt immers met name daarin uit dat alles betrekking heeft op Christus. In het hele leven is de christen aangewezen op Hem.

Men kan juist hierin iets van de motieven van Bonhoeffers "religieloosheid" aan het licht zien komen. Het gaat hem in deze christelijke zichtbaarheid in de wereld om het tegendeel van een christelijk getto. De kerk leeft niet in haar eigen wereldje van religieuze vormen en herkenningspunten die alleen voor insiders begrijpelijk zijn. De kerk leeft in Gods wereld. En ze zal dat willen weten uit de manier waarop ze haar leven inricht. Dus geen in de religie afgezonderd zijn van de wereld!

Het gaat hierin om het leven van de totale mens voor het aangezicht van God, Die zijn Schepper, en ook zijn Verzoener en Verlosser is. Dat leven kent de gehele verscheidenheid van de schepping. Juist de kerk heeft de visie ontvangen, dat het leven één is, in de mensgeworden God Jezus Christus. Dat is het wat de kerk aan de wereld heeft te betuigen.

3 In een later stadium spreekt hij jets anders over deze mandaten. Dan noemt hij in plaats van de arbeid de cultuur, en bij het huwelijk betrekt hij ook expliciet de familie. Zie Bonhoeffer (1992:392 e.v.) 
Van het bestaan van de kerk gaat zo al een getuigenis uit. Daarom is het van wezenlijk belang dat het leven van de christenen in totale harmonie is met hun belijdenis (Bonhoeffer, 1992:60). Reeds in zijn Habilitation Akt und Sein van 1931 had Bonhoeffer op een zeer diepe en wijsgerige manier laten zien hoeveel waarde hij hechtte aan de eenheid van leven en denken, van openbaring en theologie (vgl. Feil, 1991:39-52).

In de ethiek is duidelijk, dat niet slechts de eenheid van het leven voor hem van belang is, maar met name het tot haar recht komen van de bedoeling van God met dit ene leven. Hij schrijft: "Het probleem van de christelijke ethiek is het werkelijkheid-worden van de openbaringswerkelijkheid van God onder zijn schepselen" (Bonhoeffer, 1992:34). In deze omschrijving is de verbinding tussen de ethiek en een missionaire ecclesiologie met de handen te tasten!

\subsection{Kerk en wereld - het probleem}

Wanneer de kerk de roeping begint te verstaan haar gestalte in de wereld te vertonen op grond van gehoorzaamheid aan Gods openbaring, zal het niet lang duren of zij ontdekt, dat daar diepgaande weerstanden bij opdoemen. "Das corpus Christi steht ein feindseligen Welt gegenüber" (Bonhoeffer, 1992:123 e.v.). We hebben immers met een wereld te maken die zich van Christus heeft afgekeerd nadat zij Hem heeft gekend. Tegenover die wereld moet de kerk Jezus Christus als de levende Heer verkondigen. Dat is de historische verantwoordelijkheid van de kerk in het licht van de wederkomst.

Twee gevaren bedreigen de kerk daarbij: enerzijds het gevaar van een compromisgeest, en anderzijds het gevaar van radicalisme. Bonhoeffer wil met overtuiging vasthouden aan de radicaliteit van de genade. Tegelijk wil hij niet weten van een radicalisme in de zin van een antithese tegen de wereld. De achtergrond daarvan is wellicht de gedachte, dat de christenen geen "nee" mogen zeggen tegen een wereld waar God in Christus "ja" tegen heeft gezegd (Bonhoeffer, 1992:147 e.v.). In deze gedachten zit een dialectiek die wij naar ik meen niet op dezelfde manier behoeven mee te maken. We zullen in onze houding tegenover de wereld immers ook rekening hebben te houden met de concreetheid van het ongeloof. Hoewel Bonhoeffer daar op allerlei plaatsen duidelijk over is, en hij ook kan zeggen, dat er geen zwaardere zonde bestaat dan het ongeloof tegen het evangelie (Bonhoeffer, 1994:203), is deze duidelijkheid niet voortdurend aanwezig.

Sterker accent krijgt de roeping die voortvloeit uit de presentie van Christus in de kerk.

Het is de in zijn gemeente vervolgde en lijdende Christus, bij Wie recht en waarheid en menselijkheid en vrijheid een toevlucht zoeken, het is de in de wereld geen herberg vindende, uit de wereld verstoten Christus van de 
kribbe en het kruis, in Wiens hoede men vlucht en Die zo eerst de hele omvang van zijn macht openbaart (Bonhoeffer, 1992:348).

De kracht van deze woorden zit wellicht daarin, dat er niet expliciet van een roeping voor de kerk wordt gesproken, maar dat slechts verwezen wordt naar de werkelijkheid van Christus. Daarin ligt het sterkste impliciete appel. Wij zullen er niet omheen kunnen onszelf te confronteren met de vraag naar onze relatie met Christus.

Het is de vraag of onze ogen in overeenstemming zijn met het zien van Christus; of onze handen in harmonie zijn met wat Hij doet; of onze voeten willen gaan in de richting waarin Zijn Geest ons drijft.

\subsection{De verkondiging gehandhaafd}

Op deze manier is wel de radicaliteit van Jezus' werk gehandhaafd. Met zoveel woorden stelt Bonhoeffer dat het Christus niet te doen is om de oplossing van de problemen van de mensen, maar om de verlossing van de mensen (Bonhoeffer, 1992:356). De verkondiging van de kerk aan de wereld kan altijd alleen maar Jezus Christus zijn in wet en evangelie. De tweede tafel van de wet is voor hem van de eerste niet los te maken. Dat betekent dus, dat alle intens gesproken en bedoelde woorden over de christelijke existentie in de wereld niet de bedoeling hebben een anonieme existentie te zijn. Van de verkondiging, ook aan de wereld, mag niets worden afgedaan (Bonhoeffer, 1992:361 e.v.).

Het is volstrekt tevergeefs om enig doel met de wereld te formuleren zonder te spreken van Christus. Het koninkrijk van God kan niet opgaan in anonieme normen van gerechtigheid en waarheid. Zonder de naam van Christus wordt de diepste kern van het leven en van Gods doel met de schepping gemist (Bonhoeffer, 1992:403).

Toch wil Bonhoeffer er steeds iets anders bij zeggen. Wanneer de kerk alleen haar eigen bestaan op het oog heeft als doel van God, dan loopt zij het gevaar dat sterk in het rooms-katholicisme zichtbaar wordt: een doel in zichzelf te zijn, zelfgenoegzaam te zijn. De Reformatie kan evenwel op een andere manier haar bestaan tekort doen. Wanneer zij alleen de Woordverkondiging in het oog vat, en daarmee haar bestaan als plaatsvervangend omwille van de wereld over het hoofd ziet, dan is het weinig beter met haar gesteld dan met Rome (Bonhoeffer, 1992:409-411).

Ik zou dat laatste niet helemaal op dezelfde manier willen zeggen, maar de essentie ervan gaat ons wel terdege aan. Het zal de kerk in onze tijd om de eenheid van spreken en leven moeten gaan, in het diepe besef dat daarmee de missionaire roeping van de kerk staat of valt. 
Als de kerk is wat ze moet zijn, kan bij tijden haar woord zwak zijn - het zal toch betekenis hebben.

Als de kerk niet is wat zij moet zijn, in het vertonen van de gestalte van Christus, kan haar woord theologisch van het zuiverste gehalte zijn, het zal ondanks dat krachteloos zijn.

Het is met de kerk als met het Woord van God zelf. Van dat Woord immers wordt gezegd door de apostel, dat zijn prediking niet kwam met meeslepende woorden van wijsheid, maar met betoon van geest en kracht. (1 Kor. 2:4). Zo zal het zijn met de kerk, wanneer in haar het samengaan van Woord en leven, van geloof en handelen, van gebed en dagelijkse praktijk, een eenheid vormt voor Gods aangezicht.

\section{Liferatuur}

BAVINCK, H 1976. Gereformeerde dogmatiek IV, 6e druk. Kampen : Kok.

BERKOUWER, G.C. 1972. De kerk II. Apostoliciteit en heiligheid Kampen : Kok.

BONHOEFFER, D. 1954. Sanctorum Communio. Eine dogmatische Untersuchung zur Soziologie der Kirche. München : Chr. Kaiser.

BONHOEFFER, D. 1966. Widerstand und Ergebung. Briefe und Aufzeichnungen aus der Haft. Herausgegeben von Eberhard Bethge. 3. Auflage München-Hamburg : Siebenstern.

BONHOEFFER, D. 1992 Ethik Dietrich Bonhoeffer Werke. 6. Band. Munchen : Chr. Kaiser

BONHOEFFER, D. 1994. Nachfolge. 2. Auflage. Dietrich Bonhoeffer Werke. 4. Band Gütersloh : Chr Kaiser.

DE GRUCHY, John W 1984. Bonhoeffer and South Africa Theology in dialogue. Grand Rapids : Eerdmans

EBELING, R. 1996. Dietrich Bonhoeffers Ringen um die Kirche. Eine Ekklesiologie im Kontext freikirchlicher Theologie Giessen-Basel : Brunnen Verlag.

FEIL, E. 1991. Die Theologie Dietrich Bonhoeffers: Hermeneutik, Christologie, Weltverständnis. 4. Auflage. München : Chr. Kaiser.

FORD, DAVID F. ed. 1994. The modem theologians. An introduction to Christian theology in the twentieth century. Vol. I., repr. Oxford-Cambridge : Blackwell.

HEYNS, J A. 1978. Dogmatiek. Pretoria : N.G. Kerkboekhandel.

HOEKENDIJK, J.C. 1964 De kerk binnenste buiten. Amsterdam : Ten Have.

HUNTEMANN, G 1989. Der andere Bonhoeffer. Die Herausfordenung des Modernismus Wuppertal-Zürich : Brunnen

JONGENEEL, J.A.B. 1991. Missiologie II Missionaire theologie. 's-Gravenhage : Boekencentrum.

KAMPHUIS, B 1997. Als een verzegelde trein in vreemd land De radicaliteit van de navolging bij Dietrich Bonhoeffer. (In Schaeffer, J.H.F. e.a., red. Nuchtere noodzaak Ethiek tussen navolging en compromis Opstellen aangeboden aan prof. dr. J Douma Kampen : Kok. p. 127-137.)

MOLTMANN, J \& WEISSBACH, J 1967. Two studies in the theology of Bonhoeffer. New York : Charles Scribner's Sons.

MULLER, H. 1961. Von der Kirche zur Welt Ein Beitrag zu der Beziehung des Wortes Gottes auf die societas in Dietrich Bonhoeffers theologischer Entwicklung. HamburgBergstedt : Reich 
ROBINSON, J.A.T 1963. Eerlijk voor God Amsterdam : Ten Have. (Vert door D.J Beversluis. Honest to God London : S.C.M.)

RUNIA, K. z.j. Religie zonder God? Kampen : Kok.

VAN GENDEREN, J. \& VELEMA, W.H. 1992. Beknopte gereformeerde dogmatiek Kampen : Kok. 